\title{
COLLECTIVE PERSON, CONNECTED GIFT: SOME PRELIMINARY THOUGHTS ON TAONGA, WHAKAPAPA, AND 'THE GIFT' IN MAORI ART
}

Ryan O’Byrne

\begin{abstract}
In this paper I use interviews with one Maori artist to provide some preliminary thoughts on the ways Maori art can be used to understand Maori personhood. Art work is defined as taonga-whakairo and artistic talent as taonga-tuku-iho. Maori conceive both artistic talent and artistic production as taonga and I argue that the relationships between art, taonga, whakapapa and tipuna encompass networks of connections between persons, objects, and ideas simultaneously. I suggest a structural linkage between art, taonga, and exchange which form distributed social relationships. Underlying this is the proposition that artistic talent comes from the ancestors and involves particular responsibilities. Major points of argument are that: in Maori art, taonga and whakapapa interact to allow the possibility of things being persons and persons being things; taonga are fundamental to Maori concepts of tipuna and whakapapa; taonga and Maussian exchange relations are co-constituting; artas-taonga is a productive means of understanding a Maori worldview; and that further study should be conducted into Gell's (1998) 'distributed person' through analysis of taonga and Maori art.
\end{abstract}

'You know, you really need to think about the Maori world view, the way everything is so connected, and interconnected, and interrelated' - Howard, a Maori artist.

\section{INTRODUCTION}

Anthropology has long been conscious that many of the groups studied conceptualise individuals and communities in relation to descent from the people, spirits, and places which together define their individual and collective pasts. The Association of Social Anthropologists of Aotearoa New Zealand (ASAANZ) 
suggests that 'such inheritances from the past, whether conscious or not, are embedded, consciously or not, in a very wide range of contemporary social practices ... [which] also condition particular ways of being in the present' (ASAANZ, 2010). In this paper I provide some preliminary thoughts on the ways in which these inheritances are embodied in contemporary Maori art practices and worldviews. Specifically I use Maori art as a lens through which to view Maori conceptualisations of individuals and collectivities, and especially how these categories are often defined through and collapsed within each other.

Following Henare, Holbraad and Wastell's (2007:2) provocative radical essentialism, it is not my purpose here to describe an objective empirical reality about Maori art or its historical interactions with local, regional, or global phenomena. Rather, it is an exploration of that reality as experienced by one specific Maori artist. Given the quantitative limitations of this study, ${ }^{1}$ I cannot make definitive statements but instead provide suggestions for future research into the relationships between Maori art and cosmology. This position echoes that of Patterson (1992:11) who, whilst not positing a singular Maori existence, argued that Pakeha researchers must endeavour to understand Maori values and worldviews within their own terms.

In the following sections, I examine one Maori artist's articulation of how art and various Maori concepts constitute a mutually-referencing Maori world of collective persons and connected gifts. I used a Gellian approach to investigate Maori art based largely upon the fact that public knowledge of the artist and his work meant I could not focus on the aesthetic or symbolic dimensions without breaching ethical requirements of anonymity. Instead, following Gell (1998) and the specific way Howard himself spoke about his work, I analyse art as if it were a person engaging in relationships of a specifically social kind. As a result, and to paraphrase Gell, this paper is not so much about art per se as it is about a social being that just happens to be similar to art. By providing extensive quotes from the artist interviewed, I hope to do two things: first, to allow the artist 'to speak' for himself about his work and world; and secondly, to give the reader enough data that they can come to their own determinations about the validity of the argument I present and the conclusions I draw. The major argument is of an ontological rather than of an epistemological nature; it is about how art can be used to gain an insight into a Maori reality rather than an attempt to understand art itself.

I use the terms 'taonga', 'taonga-whakairo', and 'taonga-tuku-iho' throughout this paper following the definitions laid out by Mead (1997b:183-184). The 
term 'taonga-whakairo' refers to 'the process of transforming something natural into something cultural...the qualifying term enable[ing] us to try to differentiate between the taonga which is art and the taonga which is not' and taonga-tuku-iho describes those things which 'are passed down like heirlooms from one generation to the next' as 'heirloom objects' (Mead, 1997b:184; cf. Metge, 1995:49-50). Mead's definitions are particularly useful because, just as Mead was led to discuss the nature of art when describing taonga, so I have been led to discuss taonga when investigating art. Therefore, in this paper taonga-whakairo is the taonga which is culturally produced, the art product, whilst taonga-tuku-iho is that which is passed down, the artistic talent which produces that object.

The basis of my argument is that both artistic talent (as taonga-tuku-iho) and artistic production (as taonga-whakairo) can be understood as taonga within a Maori conceptual framework, and that these are linked with Maori understandings of whakapapa (genealogy or descent-line, cf. Metge (1964:52)). From this, I propose that the relationships between art, taonga, whakapapa and tipuna (ancestors) should not be understood simplistically as material in nature or unilinear in direction but instead as encompassing multiple networks of social connections between persons, objects, and ideas simultaneously. In other words, I suggest that in Maori art, taonga and whakapapa interact to allow the possibility of things being persons and persons being things. I further suggest that taonga are fundamental to Maori concepts both of tipuna and of whakapapa; that taonga and the relations involved in Maussian-based theories of exchange can be understood as co-constituting; and especially that art-as-taonga is a particularly productive means of understanding the Maori cosmological system. My recommendation is that these particular aspects of Maori art, and taonga in general, are subjected to further, more intensive study, particularly along lines of inquiry which prioritise Gell's (1998) 'distributed person' reformulation of Strathern's $(1988,1991)$ 'dividual'.

METHODOLOGY: THE ARTIST AND THE ARTWORK

As mentioned briefly in the introduction, the analysis given is grounded in a series of unstructured interviews between myself and one Maori artist. This artist, who I will call Howard, is of international renown and well respected within the New Zealand art community. In the interviews, Howard was asked to give his own interpretations of art in Maori society; what follows is largely based on his articulation of art's socio-cultural importance within Maori cosmology. Reviewers of an earlier draft of this paper recommended that, rather than claiming too much based on data from only one artist, this article should 
be written as a suggestive piece, offering ideas that others can take up for more extensive study. This I have endeavoured to do.

Howard has a number of prominent and important public or iwi-affiliated artworks situated around New Zealand. These have been funded by donors and some have been displayed in national and international museums and galleries, including Museum of New Zealand Te Papa Tongarewa. He is widely regarded by both his iwi and his hapuu ${ }^{2}$ as one of the more important and talented kaitiaki (guardian) of the stories and motifs of their tipuna, and he is the artist responsible for some of the more important artworks within his iwi. He has also held a variety of roles in which he has been able to fulfil the teaching or mentoring aspects of his kaitiaki responsibilities. ${ }^{3}$

Due to the unstructured character of the interviews, Howard was encouraged to talk about whatever seemed relevant to him about art, being Maori, or even life in general. In the process of explaining his work, Howard talked at length about Maori cosmology, the position of art in relation to this, and the complicated ways art, taonga, and Maori social relations are intimately interconnected. The art work which Howard spent most time discussing is part of an architectural installation and consists of: 'a big glass facade... A glass balustrade... [And] some lights that the architect thought would be good if they were able of tell a part of that story as well. So there were three aspects that I worked on. ${ }^{4}$ Within these different sections are several interconnected narratives telling the legend of one of the tipuna of the artist's iwi:

There are several stories in the building and they are interpretations. And the interpretation is of the ancestor... A local woman... It's a whole story about her... She is the centre of that, and a lot of the work that I did is about her exploits. So I am filling in the gaps, I suppose, filling in and broadening and using some of those key points as the starting points to express her exploits.

The purpose of this artwork was to make his iwi's stories public, and the physical expression of these stories belongs both to the artist and the iwi. ${ }^{5}$ For Howard, the motifs and symbols of his work 'come from somewhere that you explain as being spiritual... a place where concepts emerge from... And so it's working with that, the language of the ancestors, the stuff that your ancestors laid down'. He is explicit in recognising that the motifs running throughout his work have arisen from the realm of the atua (spirits/gods) and are laid down in the idiom of the tipuna. 
THE INTERCONNECTIONS OF TAONGA AND WHAKAPAPA IN MAORI COSMOLOGY AND ART

In Howard's work, 'everything is based upon the past', which is seen as a vital characteristic of being Maori and foundational to his understanding of Maori artistic expression. ${ }^{6}$ According to Howard, the fundamental knowledge needed for expression as a Maori artist is knowledge of to whom and what one is connected, and he articulated that the production of art is an expression of whakapapa connections. The way in which Howard explained these connections led me to conclude that thinking through personal issues of connection positions a Maori artist within specific whakapapa relationships with other entities and facilitates an appreciation of the full extent of the overlapping and interconnected social relationships in which they are embedded (cf. Barlow, 1991:173; Metge, 1964:52). This in turn allows self-identification and artistic expression to be framed in the idiom of ancestral predecessors. Howard agreed, and explained that:

You become aware what are the things that make you who you are and what you identify with...your history and stuff. In my terms, it's what your whakapapa is... And fortuitous that it's there, that taonga, to make reference to. It is the word of our ancestors, it is the music, it is the sounds. ${ }^{7}$

Here Howard is speaking about his own feelings of personal connection to some ancient rock carvings, where the stories and physical remains of those ancestors are both language of inspiration and material to treasure; they are concrete examples of both physical (taonga-whakairo) and ancestral (taongatuku-iho) treasures.

Taonga is a concept with multiple connotations. ${ }^{8}$ When asked to describe his art works, their inspiration, and to position them within a wider context, Howard explained how the process of artistic creation is one which uses taonga in multiple ways:

The way you do something, the technique you use, can be taonga, because it is the art of. Toi is the word that is used, toi is taonga, toi is the arts. Meaning as much how the arts are carried out, but also what is being expressed is taonga as well, because often the expression is about how the individual or the collective is thinking about something. So it becomes quite complex when you are thinking about the 
ways in which we refer to it... However, what is recognised in that is what that represents, what it expresses culturally, what it is about.

The technique used to create an artwork is taonga, as is the material product of that technique, the artwork itself. Beyond these relatively simple physical definitions, the underlying conceptual themes and genealogical connections being expressed in the artwork are also taonga, as is the very act of expression itself and the ways in which artistic inspiration is related to that expression.

Underlying this view is the idea that artistic ability is itself a form of taongatuku-iho, a gift handed down to an artist from their ancestors and involves particular responsibilities on the part of the person so blessed. Given that taonga are not just things and the processes of making things, but what those things represent and the connections and associations between them, I suggest that taonga should be defined not as 'treasure' or 'valued object' in a fashion which directs attention toward the object itself, but rather as 'something which is collectively treasured or valued'. This shifts the loci of attention away from the object toward the social milieu in which it is embedded and only through which it can have meaning. And because taonga are not just objects they are considered to have a life force as do all living things: like people they are equally agents and social actors (Henare, 2007:56; Mead, 1997b:184). As Henare argues, both taonga and people 'arise from and are generative of [social] relations. As distributed parts of persons, and as persons in their own right, taonga... are a fundamental requirement of relationality' (Henare, 2007: 62-63). Repositioning taonga as something which is unequivocally social in nature allows a conceptualisation of taonga as something explicitly non-material, such as a way of thinking or artistic skill. ${ }^{9}$

Not only does this redefinition allow the gift-of-art-talent to be taonga, but it also highlights the way Howard focuses on the taonga of thought in the passage given above. Both Howard and weaver Erenora Puketapu-Hetet (1986, 1989) trace metaphysical connections for the origins of their skills. For Howard, artistic talent is spoken of as taonga and that taonga is traced down through the tipuna to the artist. That talent therefore has whakapapa of its own and, to take it a step further, the other taonga related to that talent (the things, processes, significations and expressions created or manifested through that talent) share that talent's whakapapa. The concept of taonga is shown to encompass more than a material object. Howard explains that:

Taonga is something which is handed down to you. If your understanding, if your gift of being artistic has been handed to you by 
your ancestors [and] those ancestors received them from the atua, the gods, then that whole whakapapa of the thing [has come] from that realm.

This worldview agrees with Puketapu-Hetet's, who said 'a weaver normally experiences feelings of being linked with something greater than herself and the present...a link with nga tupuna' (1989:5) which 'is more than just a product of manual skills... [it] is endowed with the very essence of the spiritual values of Maori people... The artist is a vehicle through whom the gods create' (1989:2). It is not a large leap to assume that what applies to one Maori art form would apply to any other. ${ }^{10}$

Writing about the distinctive temporal nature of taonga, Tapsell (1997:330, cf. Henare, 2007:57; Metge, 1995:90; Salmond, 1984, cited in Henare, 2007:57; Tapsell, 2000:15) argues Maori understandings of taonga collapse time and fuse tipuna with iwi in a single whakapapa identity. Howard himself similarly speaks of the reactions of some Maori to particular images of specific tipuna:

I've heard people talk about images, of photographs, as having the mauri... It's the same as carvings hold the same kind of things, carvings can become the person. We know they're not the person, but they can become the person... It's the memory of that person being kept alive. And I don't think that that is unique to Maori society. And photographs are used in the same way. On the wharenui, we put up photographs of the ancestor who has passed on. Same as the pou pou is actually the ancestors. And you see some people react to those pou pou in different ways. I've seen old kuia, kaumatua, go up to those pou pou and rub noses with them, the same way that warriors rub noses with the waka. It's like greeting an ancestor. And that reiterates that idea that there is this living presence right there. ${ }^{11}$

Here, taonga-whakairo is seen as living because the tipuna it references are living, the ancestors are living because their spirit is living, and their spirits are living because their mauri (life-force) is being kept alive through memory. And that memory is kept alive by the artwork, completing a circular reference of continually living whakapapa connections of artwork to tipuna to artwork again. Tipuna and taonga continually reference each other, maintaining the life force of, and their life within, the distributed whakapapa relations they share. Taonga is thus a crucial step in maintaining links between whakapapa connections. Given art's structural congruence as taonga, it is taonga which maintains the life and memory of whakapapa. Although whakapapa is a series 
of associations traced through relationships between people, places and things, simultaneously it is also a distinctly living thing, something through which the maintenance and memory of social relationships enlivens the very connections used in remembering and reiterating those associations.

For Howard, at the heart of whakapapa is an ancestor: 'an ancestor is very important, because so many people can connect to that ancestor: that's what whakapapa is all about'. Having an ancestral link to whakapapa means having the ability to trace a line of connection through a particular genealogy. ${ }^{12}$ This genealogy could for example, be of blood, spirit, or talent: it is how one understands connections between significant social relationships. This knowledge is itself a form of taonga, because it is only through knowledge that whakapapa connections can be maintained. ${ }^{13}$ Important to understanding whakapapa is how it references and maintains multiple relationships between different persons, objects and things at the same time and without contradiction. Howard states that:

[There are] many different whakapapa, I guess. Different ways or layers of whakapapa... There are many different levels or layers, and some of those layers can be simultaneous. The different connections are simultaneous. Simultaneity of whakapapa... It is about connections, about layers of connections. And there are many ways. I don't even want to guess why there are so many layers. My thinking is that all the layers do connect. Even though they are simultaneous and there are different layers, they intertwine with each other. Those things need to be understood as layers. It's like, if you've got whatu weaving going that way, it all falls apart unless you have these other parts that make it all connect together. Even though there are different layers, they all work together. ${ }^{14}$

As indicated earlier, a Maori artist can resurrect and reinvigorate all the persons, spirits and things referenced by the taonga-whakairo they produce through engagement with the taonga-tuku-iho 'gifted' them through whakapapa by tipuna. Whakapapa and taonga can be said to be 'performed' through the production of taonga-whakairo from artistic-talent-as-taonga-tuku-iho. In turn, through this performance, taonga become alive with memories, acts, and inspiration invested in that taonga through whakapapa. In doing so, the taonga-whakairo produced signify the people, spirits and things embedded within the various manifestations of the taonga with which they were involved. I suggest that if we propose a structural linkage between art, taonga, and Maussian notions of gift exchange, we see that conceptualisations of art-as-taonga 
fulfils all Mauss' (1990) exchange obligations: it gives memory to those interacting with the taonga, and, through its mnemonic qualities, it gives further life to the ancestors as it simultaneously repays its obligation to those ancestors. Through this exchange, a distributed social relationship is formed among collectively connected taonga.

COLLECTIVE PERSON, CONNECTED ARTWORK: THE CONTRIBUTIONS OF STRATHERN AND GELL

In her ground-breaking analysis of Melanesian gift-giving, Strathern (1988, 1991; cf. Gell, 1998; Wagner, 1991) emphasised the notion of the 'dividual' as a 'distributed person'. The 'dividual' is someone who, due to the nature of Melanesian gift exchange, cannot be conceptualised as existing before or outside of the social relationships in which they are embedded. According to Strathern (1988:13), 'far from being regarded as unique entities, Melanesian persons are as dividually as they are individually conceived. They contain a generalized sociality within. Indeed, persons are frequently constructed as the plural and composite site of the relationships that produce them'. Strathern 'effectively created a new concept of the "person" that follows Melanesians themselves in locating personhood in the relations that exchange entails' (Henare, Holbraad \& Wastell, 2007:19).

Along similar theoretical lines, one of Gell's major anthropological insights was that art is 'seen to emerge in the overlapping set of intentionalities which are orchestrated in particular cultural contexts,... the relational basis of persons, whereby artefacts are seen to embody the same intentional complexity as persons' (Hirsch, Kuchler \& Pinney, 1997: 23). Given that I have suggested that in Maori art, taonga and whakapapa allow the possibility of things being persons and persons being things, Gell's theory makes two major contributions. The first is the proposition that art objects have or can be indicative of the causal capabilities necessary for social agency. The second is that both the artist and the artwork can be seen as social entities embodying 'distributed personhood' whose physical being and causal capabilities are distributed across multiple dimensions of time and space simultaneously (Gell, 1998: 21; cf. Strathern, 1988, 1991; Wagner, 1991).

Gell's theory depends upon the existence of specific 'art-like situations' from which one can infer an 'abduction of agency' (Gell, 1998:13). According to Gell, an anthropological theory of 'art' needs to be distinguished from anthropological theories of similar socio-cultural phenomena by being explicitly about 'artlike objects' existing in art-like social relations. In Gell's theory, the art-object 
(or 'the index') is that thing whose very existence demands the observer of that object infer the existence of another entirely independent entity which is responsible for the existence or creation of that art-object, that is, 'the index [art-object] is itself seen as the outcome, and/or the instrument of, social agency' (Gell, 1998:15, emphasis in original).

Secondly, Gell terms the observer's inference of the existence of the social agent from the object an 'abduction of agency'. The social agent here refers to an entity which can exercise social agency, where agency is defined as 'a culturally prescribed framework for thinking about causation, when what happens... is believed to happen because of an "intention" lodged in the person or thing which initiates the causal sequence' (Gell, 1998:17). Agency can be attributable to any person, thing or non-corporeal entity believed to initiate a sequence which "causes events to happen" in their vicinity', whether intended or not (Gell, 1998:16). An 'art-like situation' is the moment of this inference of an agent's existence from an object which indexes the relationship of that agent to the immediate social vicinity.

Gell (1998:222) argued that 'any one social individual is the sum of their relations (distributed over biographical time and space) with other persons.' I suggest that, in the way distributed social relationships and collective personhoods are constructed through Maori conceptualisations of connection between persons, spirits and things, this statement could hold the theoretical key to the connected nature of taonga-tuku-iho in Maori art. Howard explained to me the intricacies of Maori cosmological and conceptual worlds and the position of the artist as kaitiaki of taonga-tuku-iho:

Now, make sure you have this straight. We inherit from our ancestors a number of things. One is the whakapapa of how you live... Now, my sense is that all of those things are kind of like wairua aspects, spiritual aspects that come from right back from the atua. And those aspects that we receive are sort of like their essence in us, and that's kind of what the continuation is, in a way... Those connections are always in relation, in the end. At one level the connections are to the atua. Now, we all connect back to the atua, through that relationship that we have that is really established through that thing called wairua... I guess that it's a continuum and you are part of that continuum. What's actually important is the knowledge; it's about a guardian of that knowledge, and you're just a vehicle in a way.

Maori artwork almost always explicitly (as in motifs and narratives) and im- 
plicitly (as inspiration and the gift-of-artistic-skill) references an ancestor. ${ }^{15}$ This is 'the supreme abduction of agency from the index, in that the [ancestor's] agency is not just suffered via the index, it is also thereby perpetuated and reproduced' (Gell, 1998:227). Beyond the simple artist-equals-agent nexus, the tipuna so referenced is also an example of Gell's 'agent', and taonga-whakairo is thus an example of an 'index'. I suggest, therefore, that Maori art provides an excellent area of research into veracity of Gell's (1998) anthropological theory of art. Indeed, Gell himself suggested exactly this with his preliminary investigation of the distributed nature of social relations in the production of Maori meeting houses (Gell, 1998:251-258). Based upon the earlier discussion of the multiple connected associations between whakapapa, taonga, people, and tipuna, here I suggest two fruitful lines of future inquiry: firstly, to investigate Maori personhood (extended to include notions of 'whakapapa') as one which can conceptualised as collective or distributed; second, to open a similar line of inquiry into the collective (or connected) nature of taonga, especially exploring the interrelationships between taonga and Maori ideas of cosmology and personhood.

\section{REINTERPRETING MAUSS THROUGH TIPUNA AND TAONGA}

Origin and creation myths commonly involve an 'original debt' to the gods, spirits or ancestors responsible for that creation. According to Godelier (1999:30-31), this original debt is an obligation which can never be repaid. Exchange between the mortal and the spiritual is therefore always an asymmetrical relationship, because humankind can never repay the full extent of their debt for the 'original gift'. Furthermore, although Godelier (1999) and Weiner (1992) indicate that there exist gifts which under no conditions must be given or sold, I propose that there likewise exist those gifts that absolutely must be given and even re-given in order to have utility. I further suggest that the gift-of-artistic-talent is just such a gift: if the gift of talent is not 'given' onwards through the act of artistic production, then in some ways that talent does not 'exist' either, and the social relations allowed and maintained by that gift thus cease to exist. This is part of the responsibility of taonga-tuku-iho: to receive, to invigorate, to pass on. To give ceaselessly and socially. ${ }^{16}$

This may be one reason for the Maori prioritisation of connections to tipuna. Tipuna are the beginning of the exchange relationships inherent within taonga-tuku-iho, as well as the beginning of the universal cosmological connections between all people. They are the point in time and space where a person's connections have a physical as well as a spiritual manifestation, a reference to and moment of actualisation of taonga and whakapapa in human form. In this 
way, tipuna could be conceptualised as key to the entire taonga system. ${ }^{17}$ This is recognised by Howard, who states:

Connection to tipuna is about where you've come from. That is what is really meant when you think about a continuum. And it's about tracing your way back. You see, Maori worldview is that you always link yourself back to where you come from. The point is, how do you know where you are if you don't know where you've come from? That is what is loaded into that idea of tipuna, so tipuna are referred to all the time. So that continuum that you are in the moment of, that continuum starts with your tipuna.

Interpretations of a Maori worldview are often about linkages and descent but, in a more complex way, I argue that Howard sees his linkages as a series of connections in relation to multiple iterations of time, space, persons and things. I suggest for Howard these linkages are about tracing one's connections in genealogical time and relational space: an individual always links back to where they have come from and, as indicated previously, these links can be to multiple people, places, and times. Tipuna are the foundation for whakapapa connections, but, in turn taonga are the basis for the continual living qualities of tipuna. This, I suggest, is a further example of the circular and distributed nature of the person within the Maori cosmological system.

I have suggested above that underlying the creation and consumption of Maori art is a complex array of interconnected exchange transactions and that these form the fundamental nucleus of the different distributed social relations upon which art, taonga, and cosmological understandings are based. I have further suggested that the basis of these exchange relations can be perceived as typical examples of Maussian-type gift relations (Mauss, 1990). Art can be a gift of artistic talent from tipuna to the artist and audience; art can be a gift of art work from the artist to the audience, and, likewise, art as artwork can be a reciprocation of the art as talent to the tipuna. The three obligations of Maussian exchange are therefore deeply embedded within art-like situations in the Maori world.

The gift of artistic skill and the gift of artistic product both come with simultaneous obligations to receive, to give, and to repay. An artist is obligated to receive a gift of taonga-tuku-iho from their tipuna. As an individual artwork, taonga-whakairo can be read as the Maussian obligation to give to the audience of that art, an audience who may also be (and historically would have been) ancestors of that tipuna. That same artwork, occupying a structural posi- 
tion as obligation to repay the original gift reciprocates that gift by identifying or indicating inspiration from those who gave it: time and person are collapsed in the gift of artistic skill and the gift of artistic product, both of which are taonga and gifts simultaneously.

At the same time, the act of materialising taonga-whakairo, the inspired process of artistic creation, is the moment within which taonga-tuku-iho given to the artist reciprocates or repays previous gifts. Art is a gift in all its senses. Artistic taonga as either talent or production is thus firmly embedded within the ongoing relationships of Maori exchange indicated by Mauss (1990) and confirmed by Firth (1959). It may even be an attempt to reciprocate and repay that which was originally given and can never be repaid, human life itself (Godelier, 1999). By referencing social actors like tipuna within artistic production, the artistic act can be conceived (in both senses) as giving life to those entities, and artistic production becomes artistic conception. The original and originating gift is re-born, and the social relationship between the spiritual and the human is referenced and recreated in the social relationships between artist, artwork and audience. Through the act of creative materialisation, the object comes to embody not only the artist but all other entities involved in the flow of taonga and the creation and maintenance of whakapapa. I suggest, therefore, that in the Maori world, exchange does not create social (whakapapa) relations so much as taonga demands exchange relations. Both this aspect and those involving issues of 'origin debts' demand much further investigation within anthropological analyses of Maori art and art in general.

This argument can be taken further: through the exchange of self and taonga through whakapapa, the taonga created is one in which, at each level of the chain and at each moment in history a part of all the other connections are embedded and exist within each other (Wagner, 1991). This social relationship Gell (1998) terms distributed, one where the index can reference all aspects of all possible social relations at the same time within the same art-like object. In this instance, both taonga-tuku-iho and taonga-whakairo collapse time and space, person and thing, through the explicit referencing and counterreferencing of multiple whakapapa members (artist, audience and ancestors, as well as art works and talents) all along the social relational chains. Distributed taonga exists (Gell, 1998:96) whereby each constituent 'member' of a taonga's whakapapa connections co-exist simultaneously, in multiple times and in multiple places. Explicitly relating whakapapa to taonga, Henare argues that:

Not simply a static record of lineages, [whakapapa] is an inherently dynamic cosmological system for reckoning degrees of similarity 
and difference, determining appropriate behaviour, and manipulating existing and potential relationships to achieve desired effects. Taonga have long been crucial participants in this relational scheme... [and] were passed down kin groups, acting as (often tangible) instantiations of relationships extending across multiple generations (Henare, 2007:57).

The distributed nature of taonga-tuku-iho may therefore be produced and reproduced by social relations referenced in taonga and through gift exchange.

\section{SOME CONCLUDING REMARKS}

According to Henare, Holbraad and Wastell (2007:17-19), there are two distinct ways in which Mauss' (1990) argument can be understood: one is epistemological, the other ontological. The first regards persons and things as distinct categories of wider empirical reality which Maori merge into one; the other treats persons and things as concepts rather than realities, in an attempt to understand entirely alternate ontological definitions to our own. As Sissons (2011 pers. comm., cf. Johansen, 1954; Sissons, 2011:629) has pointed out, 'Johansen argued that if Kant were Maori kinship would be an a-priori category like space or time.' This statement indicates the necessity to question our categories of analysis, particularly those which question base understandings of self, person, and society, and concurs with Metge (2002:317) who states that 'the metaphysical element in Maori thinking is...too prominent to be ignored'.

It is this aspect which is why I think that Henare, Holbraad and Wastell's (2007) radical essentialism is appropriate to the study of taonga exchange in Maori art and its context within wider a Maori worldview. By redefining questions of exchange within an ontological rather than epistemological paradigm, we can ask not 'what does the nature of Maori reality say about the nature of exchange?' but rather 'what can art and Maussian conceptualisations of exchange tell us about the nature of a specifically Maori reality?' It seems this would be another fruitful avenue of future research, because in Howard's own descriptions, the values and practices inherent within exchange; the agency of objects; and distributed connections of people, things and gifts intermingle in complex and co-constituting ways.

Unlike Mauss (1990:11), I propose that it is not 'gifts' which compel exchange obligations in the Maori social world but rather taonga itself: it is the distinctive living force (mauri) of taonga embedded within whakapapa which demand the maintenance of the social relations underlying exchange rather 
than, as Mauss argued, the hau of the gift. ${ }^{18}$ In other words, I suggest that an examination of Maori exchange relations using Gell's art-like situation as an analytical framework, produces the theoretical insight that it is not 'the gift' or exchange practices which create and maintain social relations so much as it is the nature of taonga to demand, produce, and maintain exchange relations.

In this paper I have argued that taonga-tuku-iho can be understood as a process of referring to historical persons, objects and spirits which are considered embedded within simultaneous layers of connections. This understanding of taonga is enabled by the particular ways in which art in the Maori world simultaneously functions as treasure, as means of social and historical connection, and as Maussian gift. Artistic-talent-as-taonga and taonga-whakairo that it produces share whakapapa. Taonga-whakairo as product of that talent is connected to all other entities in those relations by virtue of the distributed nature of mauri embedded within the artwork. In this way, taonga-whakairo manifests the connected social relationships which constitute and allow whakapapa. It similarly manifests tipuna.

Whakapapa in turn functions as a means of connecting persons and things in the same way that the artist and the artwork co-constitute the multiple connections of taonga-tuku-iho. Howard articulates the connections between his social and metaphysical worlds by saying:

I suppose in the end, it's a way of saying again who and what you are. When I'm saying that, 'who and what you are', the more times that I say that, the 'who' is not who singular, the 'who' is who you are collectively, who am I a part of, not who you are singularly. And so that's who I am trying to find out who I am, who am I connected to, as a connected person, who am I connected to. Who am I as a part of a whole continuum.

Patterson (1992:110) and Johansen (1954:35-37) similarly argue that not only do Maori individuals often identify personhood with a kin group, but personal pronouns such as 'I' are used to speak about both an individual and their whakapapa.

By attempting to frame these subjectivities in an ontological paradigm, it may be possible to go beyond positions such as 'the "native" thinks X about reality' and make statements such as 'the "native's" reality is X'. This is a further strength of Henare, Holbraad and Wastell's (2007) radical essentialism: it asks us to go beyond interpretation of another's worldview into our own reality 
and attempts to put aside that reality in an endeavour to understand another's worldview in its own terms. I believe that this theoretical position offers great potential for an anthropological analysis of Maori art, as it means going beyond stating that 'some Maori view their selves as part of a collective' and instead knows some Maori selves to be collective.

Finally, I suggest that in contemporary Maori existence taonga and whakapapa mediate, reference, and transmit agency and the existence of social relations from the past into the future and vice versa. They bring together the past and the future by allowing time to unfold in a particularly connected way. Due to this relational similarity between taonga and whakapapa, and echoing Henare (2007:57), I propose that whakapapa relations and artistic-taonga both fit Gell's (1998) example of social entities distributed in time and space, as both are social relations of some kind: art as a distributed 'talent' or 'gift' is a particular kind of exchange relation and whakapapa as a distributed 'person' is a particular conceptualisation of the connections underlying kin-like relations. I argue, therefore, that taonga tuku iho should be understood not only as something passed down to an individual or a group by their ancestors but rather as something which connects those individuals and groups to others; taonga, rather than being mere physical manifestations, should be understood as something within which Maori social relationships are embedded. However, given the limitations of the research underpinning this argument, I again emphasise that these statements require much further substantiation.

\section{ACKNOWLEDGEMENTS}

I would like to thank the two anonymous reviewers for their insightful and important comments on and contributions to the development of this article. Any residual faults remain those of the author. Particular thanks go to Dr Catherine Trundle for her support throughout the process of researching and writing the Honours-level paper which forms the basis of this article, as well as her help turning that paper into this one. I would like to thank Associate Professor Jeff Sissons for his many important comments, especially with regard to the literature, and Drs Diane O'Rourke, Hal Levine, and James Urry for always having open doors and the time to talk. Finally, to Marie: without you I would have nothing. Thank you. 
NOTES

1 This paper is based upon research carried out as an honours-level anthropology paper at Victoria University of Wellington, thus the limitations in size and scope.

2 Although iwi is usually defined as tribe, Webster (1997:325-331, 2002:358-359) points out that this may be a recent rendering of political affiliations between hapuu which, rather than being defined as 'sub-tribe', should perhaps be defined as 'tribe'.

3 According to Mead (1997:165), Metge (1995:68) and Patterson (1992: 92-94), the responsibilities of a kaitiaki include not only the safe-keeping of taonga but also the provision of a future for that taonga by passing on all relevant knowledge.

4 Unless explicitly stated, all quotations in this article belong to Howard.

5 For instance, Metge (1995:70) states 'stories about...members of past and present generations... are recognised as whanau property as surely as tangible objects'.

6 This is similar to descriptions of Maori time and history given by Salmond (1982) and Patterson (1992:65).

7 This worldview agrees with Mead (1997:161), who states 'our traditional arts provide a direct link to our ancestors. We can say that these are the motifs which they thought important for us, here are the techniques they used to create these objects, and here are the materials they used'.

8 For instance, although Williams (1971:381) defines taonga as 'property, anything highly prized', Metge (2002:338) states it can apply to land, people, arts and knowledge. A specific example comes from Howard who says 'taonga has been defined by the Waitangi Tribunal [as] those things that you treasure... [But] you can treasure the air you breathe... Everything really is taonga. Everything in the whole universe is taonga, in a lot of ways: it's how we think about it'.

9 A reviewer of this paper asked whether a mode of thinking could be considered taonga or whether thought/knowledge could be considered talent. In response to this, I direct the reader's attention toward Barlow (1991:173), King (1978:12), Mead (1997b:182, 184), Metge (1995:69, 2002:338) and Patterson (1992:31).

10 In fact, Patterson (1992: 25) argues that this 'point about weaving applies also to carving'. 
11 Mead (1997:184) likewise states 'one of the reasons there is a high spiritual aspect to some taonga is that they represent an ancestor who is related by whakapapa to a group of descendants. For the living relatives the taonga is more than a representation of their ancestor; the figure is their ancestor'.

12 Barlow (1991:173) and Metge (1964:52) indicate that whakapapa connections can be multiple and simultaneous and that it is only a matter of which whakapapa are prioritised at any one time. Barlow further notes that whakapapa are not only to people but also to creation, gods, animals, mythological beings, and Hawaiki canoes. Interestingly, in an extension of the next quote below, Howard also makes all these same whakapapa himself.

13 See note 9, above.

14 The worldview which Howard displays echoes that of Puketapu-Hetet (1986:4041, 1989:59), who uses weaving metaphors when discussing the bonds which hold families and communities together.

15 For example, Mead (1997:163) states art in meeting houses always relate to particular ancestors and their stories.

16 This may be an example of Weiner's (1992) 'keeping-while-giving' but limitations of the research preclude analysis here. It should, however, be investigated in future study.

17 Taonga could likewise be regarded as key to understanding whakapapa as well, but that is beyond the scope of this research and needs to be analysed by a larger project.

18 Due to Ranapiri's description of taonga exchange, Mauss argued that exchange carries hau, 'the spirit of the gift', which he treated as the spirit of the persons engaging in exchange (Mauss, 1990:11). Salmond (1978:16), on the other hand, defines 'hau' as 'vitality, breath... return gift', emphasising the object, the exchange, and that inside the object. However, as Henare (2007: 48, possibly following Firth, 1959 and Metge, 2002) notes, Ranapiri actually states that hau is not that of those involved in the exchange but rather of taonga itself. Hau, therefore, should be understood not as an essence of someone carried by taonga but rather as the life force of taonga: it is the object not the exchange which should be given central import. 
Article - O’Byrne

\section{REFERENCES}

Association of Social Anthropologists of Aotearoa/New Zealand (ASAANZ). 2010 Whakapapa/Genealogies/Ancestor. Retrieved from http://tur-www1.massey. ac.nz/ wwasaanz/Theme.html

Barlow, C. 1991 Tikanga Whakaaro: Key Concepts in Maori Culture. Auckland: Oxford University Press.

Firth, R. 1959[1929] Economics of the New Zealand Maori. Wellington: Government Printer.

Gell, A. 1998 Art and Agency: An Anthropological Theory. Oxford: Clarendon Press.

Godelier, M. 1999 The Enigma of the Gift. Chicago: The University of Chicago Press.

Henare, A. 2007 'Taonga Maori: encompassing rights and property in New Zealand', in A. Henare, A., M. Holbraad, and S. Wastell (eds) Thinking Through Things: Theorising Artefacts Ethnographically. London: Routledge: 47-67.

Henare, A., M. Holbraad, and S. Wastell 2007 'Introduction: thinking through things', in A. Henare, A., M. Holbraad, and S. Wastell (eds) Thinking Through Things: Theorising Artefacts Ethnographically. London: Routledge:1-31.

Hirsch, E. Kuchler, S. and Pinney, P. 1997 'Obituary of Alfred Gell', Anthropology Today, 13(2): 21-24.

Johansen, P. 1954 The Maori and his Religion in its non-Ritualistic Aspects. Copenhagen: Munksgaard.

King, M. 1978 The Mauri Ora: Aspects of Maoritanga. Wellington: Methuen.

Mauss, M. 1990[1923] The Gift: The Form and Reason for Exchange in Archaic Societies. New York: W.W. Norton.

Mead, S.M. 1997a 'Dimensions of meaning in Maori art', in Landmarks, Bridges and Visions: Aspects of Maori culture. Wellington: Victoria University Press: 157-166. 
Mead, S.M. 1997 b 'The nature of taonga', in Landmarks, Bridges and Visions: Aspects of Maori culture. Wellington: Victoria University Press:179-189.

Metge, J. 1964 A New Maori Migration: Rural and Urban Relations in Northern New Zealand. London: The Athlone Press.

Metge, J. 1995 New Growth from Old: The Whanau in the Modern World. Wellington: Victoria University Press.

Metge, J. 2002 'Returning the gift - utu in intergroup relations: in memory of Sir Raymond Firth', Journal of the Polynesian Society, 111(4):311-338.

Patterson, J. 1992 Exploring Maori Values. Palmerston North: The Dunmore Press.

Puketapu-Hetet, E. 1986 'Interview', in D. Nicholas (ed) Seven Maori Artists: Interviews. Wellington: Government Printer.

Puketapu-Hetet, E. 1989 Maori Weaving With Erenora Puketapu-Hetet. Auckland: Pittman.

Salmond, A. 1978 'Te Ao Tawhito: a semantic approach to the traditional Maori cosmos', Journal of the Polynesian Society, 87(1):5-28.

Salmond, A. 1982 'Theoretical landscapes: on cross cultural conceptions of knowledge', in D. Parkin (ed) Semantic Anthropology. London: Academic Press: 65-87.

Salmond, A. 1984 'Nga huarahi o te Ao Maori: Pathways in the Maori world', in S.M. Mead (ed) Te Maori: Maori Art From New Zealand Collections. Auckland: Heinemann:109-137.

Sissons, J. 2011 'Comment: anthropological understandings of hapuu and the improvisation of social life', Journal of the Royal Anthropological Institute (N.S.), 17: 628-631.

Strathern, M. 1988 The Gender of the Gift. Berkeley: University of California Press.

Strathern, M. 1991 Partial Connections, ASAo Special Publication no. 3. Savage, MD: Rowman and Littlefield. 
Article - O’Byrne

Tapsell, P. 1996 'The flight of Pareraututu', The Journal of the Polynesian Society, 106(4):323-374.

Tapsell, P. 2000 Pukaki: A Comet Returns. Auckland: Reed Books.

Wagner, R. 1991 'The fractal person', in M. Godelier and M. Strathern (eds) Big Men and Great Men: Personifications of Power in Melanesia. Cambridge: Cambridge University Press: 159-173.

Webster, S. 1997 'Maori hapuu and their history', The Australian Journal of Anthropology, 8(3):307-335.

Webster, S. 2002 'Maori retribalisation and Treaty rights to the New Zealand fisheries', The Contemporary Pacific, 14(2):341-376.

Weiner, A. 1992 Inalienable Possessions: The Paradox of Keeping-While-Giving. Berkeley: University of California Press.

Williams, H.W. 1971 A Dictionary of the Maori Language. Wellington: Government Printer. 